IFN Working Paper No. 836, 2010

\title{
North Korea: Fading Totalitarianism in the "Hermit Kingdom"
}

\author{
Benjamin Katzeff Silberstein
}




\title{
North Korea: Fading Totalitarianism in the "Hermit Kingdom"”
}

\author{
Benjamin Katzeff Silberstein
}

May 13, 2010

\begin{abstract}
North Korea is perceived by many as one of the most totalitarian societies of modern time. But in the wake of the economic collapse of the 1990s, North Korean totalitarianism has grappled with new conditions. This paper examines how the country's totalitarian character has been upheld through the institutional changes instigated by the economic collapse and subsequent famine in the country. It strives to answer whether today's North Korea should still be characterized as a totalitarian society, and, if not, what system then governs the country.
\end{abstract}

JEL Codes: P20, P30, P36

Keywords: North Korea; Totalitarianism; Authoritarianism; Institutional Change; Planned Economy; Social Control

Research Institute of Industrial Economics (IFN)

Box 55665

SE-102 15 Stockholm

Phone: +46-8-665 4500

Fax: +46-8-665 4599

e-mail: Benjamin.Katzeff@ifn.se

\footnotetext{
* I am grateful for useful comments and suggestions from Magnus Henrekson and Fredrik Sjöholm at the Research Institute of Industrial Economics (IFN).
} 


\section{Introduction}

North Korea is perceived by many as the most controlled and oppressed society in the world today. It tops many of the global standardized ratings of political repression, and is in fact considered by some to be the longest surviving totalitarian regime in the world. The political control incorporated in the North Korean society apparatus is so strong that the North Korean regime has remained unthreatened by political opposition for decades, despite the fact that North Korea is, according to Nicholas Eberstadt, "[...] [T]he first urbanized literate society in human history to suffer famine during peacetime."”

Indeed, North Korean society was - at least when it functioned as intended - almost an embodiment of the textbook definition of a totalitarian society. Pre-1990s North Korea even stood out from other societies considered to be totalitarian, perhaps most notably in its total lack of political dissidence. According to both scholars and refugees who have fled North Korea, no political opposition or dissident movement has ever existed in the country (Hassig and Oh 2000, ch. 6, various pages). The North Korea in the years before the 1990s was not merely "any" totalitarian society - its level of totalitarianism was unprecedented in contemporary history.

But a totalitarian society requires that its institutions actually function as intended in order for totalitarianism to work. This was not a significant problem when North Korea was economically stabile. But as the 1990s approached, the dire state of the country's economy took an increasingly larger toll on the public agencies controlled by the regime. It has thus become questionable whether the country that was long considered to be the most totalitarian society of all times is still actually totalitarian. This paper aims to explore exactly that: did North Korean totalitarianism survive the economic crisis of the 1990s?

\footnotetext{
${ }^{1}$ Eberstadt 2009, p. xi.
} 
If totalitarianism is fading in North Korea, the country may well be becoming what Andrei Lankov calls more "normal". ${ }^{2}$ A transformation in the social nature of the country would have profound implications for the entire region. A non-totalitarian regime would, in the long run, be forced to answer to the demands of the population in a different way than a totalitarian one. North Koreans would probably not accept the economic mismanagement and isolationist strategies of the totalitarian regime, forcing it to reform in order to stay in power. ${ }^{3}$ And a reformed North Korea would be likely to become economically interdependent, and thus probably more peaceful (Cargill 2009). Should the regime, however, choose not to change, the chances of a collapse in the long run are significant. Whatever the fate of North Korean totalitarianism may be, it will have far-reaching implications for many other countries beside North Korea itself.

This issue is not unexplored. For example, Andrew Scobell has provided a thorough overview of North Korean totalitarianism in a previous issue of the North Korean Review (Scobell 2008). I do, however, hope to provide a different framework and focus of analysis than previous researchers have, and that my perspective is able to enrich the discussion on changes in North Korean society.

\section{Theoretical Framework - What is Totalitarianism?}

Totalitarianism is first and foremost a political system in which the ruling regime holds political control over all of society by commanding vital political and social institutions. It tolerates none or very few threats to its mandate to exist, and justifies oppressive measures with the "ultimate end" of the system, the stage when the state's ideological goals will finally be met. Political scientists differ on the exact definition of totalitarianism, but this can be said to be the very core of the concept. It is the dynamic, "organic" cooperation between different

\footnotetext{
${ }^{2}$ Lankov 2006a.

${ }^{3}$ For more on this issue, see Park 2009.
} 
totalitarian segments that creates the cluster of totalitarianism. Without one of them, or with only some of them, a society cannot be considered totalitarian (Linz 2000, p. 9). It is the purpose of this essay is to explore whether this dynamic exists in the North Korean society.

What characteristics, then, define the totalitarian society? Juan Linz, one of the scholars who has developed the concept further by building on the works of Zbigniew Brzezinski and Carl J. Friedrich, Hanna Arendt and others, suggests three main features: a monistic center of power; an ideology developed, justified and pursued by the leadership; and mass participation in political and social goals encouraged and even demanded by that same leadership (Linz 2000, p. 70). This definition is more flexible than the one that Juan Linz has dubbed "classical”, that posed by Brzezinski and Friedrich. But it is also vaguer than Brzezinski's and Friedrich's definition, which establishes six "traits" creating the totalitarian "cluster". Their defining list deserves to be quoted in full:

1. “An official ideology ...covering all vital aspects of man's existence to which everyone living in that society is supposed to adhere ... [the ideology] is characteristically focused and projected toward a perfect final state of mankind ...;

2. A single mass party led typically by one man ....and consisting of a relatively small percentage of the total population ... a hard core of them passionately and unquestioningly dedicated to the ideology ... such a party being...typically either superior to, or completely intertwined with the bureaucratic government organization;

3. A system of terroristic police control...characteristically directed not only against demonstrable 'enemies' of the regime, but against arbitrarily selected classes of the population; the terror of the secret police systematically exploiting modern science, and more especially scientific psychology; 
4. A technologically conditioned near-complete monopoly of control, in the hands of the party and its subservient cadres, of all means of effective mass communication, such as the press, radio, motion pictures;

5. A similarly technologically conditioned near-complete monopoly of control (in the same hands) of all means of effective armed combat;

6. A central control and direction of the economy... typically including most other associations and group activities."4

The authors later revised and added further comments to their description. In doing so, they emphasized the fact that the party intertwined with the government bureaucracy does not necessarily have to be a political party as such. The vital point is that monopolistic control is in the hands of society's ruling elite (Linz 2000, pp. 65-66).

\section{Alternate Labels}

Yet what political system rules North Korea if not totalitarianism? To answer this question, a number of closely related but alternate labels can be contrasted with contemporary North Korea.

1) Eroding totalitarianism essentially refers to a state where totalitarianism is the basic political system, but where that system is breaking up in one or many aspects.

2) Post-totalitarianism suggests a state of structural totalitarianism, but with a weakened central power that allows for other group interests, such as those relating to class, regions, economical or other bureaucratic spheres to take root and affect politics. Thus, posttotalitarianism involves a sort of pluralism that does not exist in the totalitarian society. In this political system, ideology turns into a mere instrument for those in power, and is adapted to other forces than purely the regime's political goals (Linz 2000, p. 115; Scobell 2006).

\footnotetext{
${ }^{4}$ Brzezinski and Friedrich 1956, p. 9-11.
} 
3) Authoritarianism is often confused with totalitarianism. Authoritarianism refers to a lighter stage of political control, and theorists often refer to authoritarian regimes rather than societies, as in the case of totalitarianism. This is because the distinction between regime and society is not fully obliterated in the authoritarian society, just as the rulers intend. There exists a limited form of pluralism that is not present in the totalitarian society, and the functions of the institutions in the authoritarian regime may vary between countries and regimes. Instead, what defines the authoritarian regime - which can of course take a great number of different forms - is, according to Juan Linz, the existence of a leader and occasionally a group that exercises power within informally defined but still "quite" predictable limits. Political pluralism can exist, but it is devoid of real power. Political mobilization may also exist at some points in the regime's history, but it is not the norm, as seen in the totalitarian society (Linz 2000, pp. 159-161).

4) The failed (or failing) state implies a situation where one or many of the regime's institutions exist, but have essentially ceased to function. The failed state is disorganized; political authority disappears - fails - and the economy declines, control over citizens weakens, and authority over large parts of territory is lost. The overall authority of the state is in decline, which is illustrated by a variety of factors, including refugee flows (Foreign Policy Magazine 2009).

I now turn to the actual analysis of today's North Korea to assess whether totalitarianism is still the country's prevalent political system.

\section{The Current Status of Totalitarianism in North Korea}

\section{The "Official Ideology"}

In official terms, North Korea's ideology does not seem to have changed much since the beginning of the economic crisis. The constitutional revision of 1998 did not significantly 
alter the nature of ideology's function and importance - Juche is still mentioned in the first sentence. The introduction of new ideological concepts in politics, such as Songun ("militaryfirst-politics") and Kangsong Taeguk ("Strong and Prosperous Nation" - a supposed leading strategy in strengthening North Korea's economy and military) is probably best interpreted as a new emphasis on the military-oriented segment of Juche, which has gained importance since Kim Jong Il formally took power in North Korea through his position in the military (Lee et al 2009; Kim 2003, pp. 88-89, p. 66, pp. 91-92). Some have argued that the introduction of Kangsong Taeguk implies an ideological move towards economic opening, but the concept itself and the circumstances during which it was introduced rather points towards it standing representing a hardening of Juche ideological rigor (GlobalSecurity.org 2009; Kim 2003, p. 66).

A revision of the Juche ideology would have been logical in the wake of North Korea's economic collapse. Juche calls for complete economic independence, but the disintegration of the North Korean economy has in fact made the country entirely economically dependent on its worst political enemies. The regime appears to have chosen denial as the strategy for continuing to justify the Juche ideology for its own population. According to a study conducted in the fall of 2009, 43 percent of North Korean refugees had never even heard of the international food aid to the country, which at one point fed more than one-third of the population (Chang et al 2008). Of course, the state's very recognition of economic problems could be interpreted as passive admittance of the failure of the Juche ideological doctrine, but nothing of the sort seems to be visible in North Korean rhetoric.

Yet North Korea continues to employ the totalitarian ideology as described by the totalitarian framework. The ideology not only exists, but is inscribed in the country's constitution, and very little points to actual changes in ideological theory and rhetoric. 


\section{The "Single Mass-party"}

Has North Korea's power center - the single mass-party - managed to survive the economic collapse and uphold its position? The power center's strength seems intact, but its structure has been slightly altered. A significant power shift has occurred from the party to the army, but the monolithic power center as such remains. Even though the North Korean constitution states that the Worker's Party should provide leadership for "all activities" within the republic, many consider North Korea to be ruled by the military rather than the party. This order has supposedly been in place since the instigation of "Military First Politics", Songun, an explicit political strategy which states that the military should be given priority in politics and resource allocation. The chairmanship of the National Defense Commission (held by Kim Jong Il) is, according to Kim Yong Nam (the president of the North Korean parliament's presidium) the "top post of the republic", 5 being made so through a number of intentional constitutional reforms.

Many signs in recent years have suggested a power struggle between the allegedly more conservative military apparatus, and the supposedly more progressive and reform-friendly party. Although factual information is a rare luxury, the fact that the power shift has been explicitly announced through judicial measures gives little reason to question the military's increased power within the state apparatus. Likewise, anecdotal evidence from within the institutions fuel the claim of a power struggle (see for example Oberdorfer 2001, p. 422).

But what does this mean for the political system? As noted, it is not an explicit criterion for totalitarianism that society be ruled by a totalitarian political party. Rather, it is the existence of a center of power that provides the totalitarian mechanism. In other words, whether the party or the army acts as the totalitarian center of power is not important.

\footnotetext{
${ }^{5}$ Kim 2003, p. 91.
} 
However, the very existence of a split between two separate power centers is interesting, as it implies at least some degree of pluralism, which should not exist in a totalitarian society because of the risk of splits and factionalism. These separate power centers could give rise to an (admittedly very limited) pluralistic climate of opinion, which could in turn threaten the totalitarian regime's unitary totalitarian power. When totalitarian power is divided, room emerges for alliances between interests outside the control of the regime, which may in turn threaten society's political unity. But then again, the implications of this should not be overstated by any means. No matter which sector of the state apparatus enjoys main political power, they are all part of the regime as such. Thus, the threat towards the regime's power is probably fairly limited. This is emphasized by Juan Linz, who cites the example of the struggles between the SS and the SA in Nazi Germany, a relationship that was likely tenser than that between the army and the party in North Korea today (Linz 2000, pp. 68-69). That does not mean that the structures of Nazi Germany were not totalitarian, or that North Korea is not totalitarian in this respect; it simply implies the possibility of an opening towards posttotalitarianism. But the North Korean power center is still far from that stage.

\section{The System of Police Control}

According to some of the most knowledgeable scholars, the economic crisis and subsequent famine of the 1990s have in many respects drastically weakened the North Korean system of police control. This is mainly due to the poor state of the North Korean economy and the state's inability to pay its security functionaries, including security guards and the heads of the inminban ("people's groups"). ${ }^{6}$ Much indicates that bribes have become more and more common, and that they are making it increasingly easier to avoid punishment for

\footnotetext{
${ }^{6}$ The term inminban roughly translates into "people's groups". Each North Korean citizen is allocated to an inmiban depending on place of residence, and all group members are responsible for the surveillance of each other. The head, the inminbanjang, stands in regular contact with the security authorities and is responsible for reporting any criminal activity or other political disobedience to them (Lankov 2006b).
} 
“political crimes" such as possession of foreign (mostly South Korean) literature and similar items. The inminbanjang (heads of the people's groups) used to be one of the political police's most important social proxies within the population, and indeed they still are. But their rigor has probably diminished due to the breakdown of the public distribution system (PDS). One of the incentives for the inminbanjang used to be larger rations, as payment for the assignment (Lankov 2007, pp. 173-177; Lankov 2006b). But today, the PDS barely operates, resulting in less incentive for the inmibanjang to uphold social control. Like the police, they are likely to be quite receptive to bribes as a way to increase their income after the decrease in rations from the PDS. The system's function has thus been greatly weakened in the aftermath of the economic crisis.

The harsh restriction of freedom of movement has also subsided due to the breakdown of the official economy. Bribes have become an institutionalized tool for gaining travel permits for both domestic and cross-border travel. At first, control of domestic travel foundered because the state wasn't able to keep people from searching for food in other provinces than their own. But later on, restrictions on travel have become fairly easy to evade by bribing officials for permits (KINU 2008; Lankov 2007, pp. 180-184; Lee, Joo Il 2009). Travel to China - has also become possible through the institutionalization of bribery, even though it is still forbidden by law. The fact that police control has been so weakened that North Koreans can leave the country without major complications is an indication of the severity of the collapse. The breakdown of police control through bribery has effectively damaged the function of the North Korean system of control as a whole; many of the tools the state had used to ensure control have eroded.

It is interesting to note how the North Korean class system has been affected by the increased inefficiency of the system of control. The groups in the lowest strata have, according to some, been able to climb the social ladder, as they generally live close to the 
Chinese border, the least hospitable areas of the country. Because they live so close to China, they are able to make "unofficial" money through illegal cross-border trade. Their proximity to China has thus granted them a comparative advantage in trade, with some saying that the whole songbûn-system has been damaged by these geographic perks.

Other social aspects of police control have lost significance too. The Maoist-inspired "selfcriticism" sessions have reportedly diminished in importance and frequency since the 1990s. These sessions exploited basic human psychology by creating animosity and suspicion between people, who were forced to criticize each other's actions and behavior at the workplace on a daily basis. But much indicates that the sessions are no longer practiced with the same frequency as before (Lankov 2007, pp. 35-37).

However, it should be noted that even though police control in North Korea may have diminished since the breakdown of the economy, coercion and police terror are still very much present. Though the rate of arrests and police coercion - or "terror" - seems to vary quite significantly over time, it remains clear that police control is still a reality.

Finally, is contemporary North Korea totalitarian with respect to the third criterion? Since it is apparent that the system of police control is weakening, one could hold that the third criterion of totalitarianism is eroding: the structures still exist, but the system is not functioning as intended - it is gradually breaking up. This is indeed what seems to be happening. The terror has decreased in rigor because of the regime's inability to finance the system, with cracks developing as a result. As noted earlier, the system continues to be very strong, but the fact that it has weakened considerably implies that the terror is no longer allpervasive. One could also consider the current status of the North Korean system of control as approaching the post-totalitarian stage.

The abatement of control has given rise to a rather vague interest group consisting of the traders along the Sino-Korean border and in the formerly outlawed black markets of the 
country. Their group interest was recently made apparent when large numbers of traders engaged in rare displays of anger after a recent currency reform caused them to lose large sums of money (Choi et al 2009; Yoo 2009). According to Juan Linz, real change can occur in a totalitarian society when policymakers establish links with interest groups in society (Linz 2000, p. 115). But in North Korea at present, the interest groups exist, yet the links between them and policymakers seem not to, even though many of the traders are likely to be party members of high standing. And, even though cracks in the system - such as crossborder trade - have been institutionalized, they have not been formally recognized, and the regime has in fact made some attempts to roll back the development. With respect to the system of oppressive police control, North Korea is probably best described as an eroding totalitarian society, with good future prospects of reaching post-totalitarianism. The prerequisites for post-totalitarianism exist, but they are not fully developed.

\section{The Monopoly of Mass Communication}

It is clear that the economic crisis and the regime's subsequent inability to fully finance its institutions have greatly eroded the monopoly of mass communication. Weakened border control has made the flow of foreign influences into North Korea possible, and not least South Korean influences have found their way into the country (Hassig and Oh 2008). It is doubtful that one can speak of an actual monopoly of mass communication in today's North Korea due to the fact that an alternate flow of information exists.

The breakdown of border control towards China has propelled this process by enabling South Korean culture to be smuggled into North Korea. There is reportedly an unofficial word for South Korean music obtained from China, "Yanbian Music". The word emanates from the Chinese region Yanbian, near the border to North Korea, which is known for its extensive population of ethnic Koreans and South Korean businessmen. Furthermore, a steady stream of 
news reports has followed in the wake of popular culture. It needs to be emphasized that South Korean, Chinese or any sort of cultural influx provides North Koreans with news previously unknown to most. Supposed poverty and suffering in South Korea and in the capitalist world in general has been a dominant theme in North Korean propaganda for decades, which has claimed that the standard of life and human rights in the country is higher than in most other parts of the world. Although smuggled movies and television shows rarely present a true representation of reality, they still show living standards in other countries - in South Korea in particular, in the North Korean case - by just having been filmed there. They passively depict the relative affluence in the western world, showing the high density of cars on the streets for example, or the standard of clothing worn by the general public. This deprives the North Korean regime of a great deal of its legitimacy.

The habit of listening to foreign radio broadcasts is also an ever-growing trend in North Korea. It is not possible to accurately measure the number of North Koreans who listen to foreign radio broadcasts today, but survey studies conducted among refugees in China and South Korea have indicated that as many as 87 percent had either listened illegally to radio stations such as the South Korean public service station Korean Broadcast Service or knew of its broadcasts in North Korea, prior to defecting. Forty percent listened to the KBS more than twice a week, and another 40 percent claimed they had been listening on a daily basis (Hassig and Oh 2009, p. 161). This population may very well be skewed - those who defect probably often hold a less favorable view of the regime and are therefore more prone to disobey its rules and laws. But the fact that such a high percentage of a non-explicit elite sample of people has repeatedly listened to illegal radio broadcasts, whose news on the North Korean regime tends to be anything but favorable, indicates that the monopoly on mass communication has not only begun to erode, but has been heavily damaged. Some North Korean defectors' groups in South Korea and China even claim to regularly speak to North 
Koreans along the border to China with cell phones. If such a direct flow of information actually exists, the long-term consequences could be dramatic. After being continuously exposed to non-propagandistic news about the country, North Koreans may start to question the propaganda that the regime is presenting to them. They might thus begin seriously questioning the regime in the long run.

As Brzezinski and Friedrich note, the propaganda in a totalitarian society is used to maintain the power of the ruling regime; it is clear that the North Korean state is beginning to loose a strong weapon. In fact, some signs indicate that the regime is even starting to adapt to this new order, thereby recognizing and even admitting to some validity in the implications inherent in the flow of South Korean culture. One example is cited by Andrei Lankov, who holds that the regime now tries to promote itself as the more purely Korean and nationalist alternative instead of claiming to be economically superior to South Korea (Lankov 2008). Thus, even though the regime still strives for totalitarian control by trying to subvert outside influences and uphold its monopoly on mass communication, North Korea is in this respect approaching a post-totalitarian system, where the strategies of the regime continuously adapt to a changing reality.

But then again, it should be remembered that North Koreans showed very little signs of open contempt towards the government even during the worst days of the famine, and no substantial political opposition has ever been organized inside the country. Thus, despite that North Korea may be moving towards post-totalitarianism, it remains doubtful whether the transformation would have any real implications for the country. Its Confucian heritage contributes to preventing all forms of organized political dissent for some time to come, even in the absence of a state monopoly on mass communication. After all, the regime has managed to muddle through the major economic crisis of the 1990s. If it can combat such an 
obvious challenge to its legitimacy, it may well be able to successfully manage the flow of outside influences into the country.

Whatever the implications, it is clear that the regime's monopoly on mass communication is eroding. Should the erosion continue, a post-totalitarian stage where the regime adapts itself even more and accepts the flow of information from the outside world could follow. And, last but not least, as the flow of information is maintained at the current level, or grows larger, the population will continue to grow even more aware of a reality that is a challenge to the regime, which continues to claim that its system is superior to all alternatives.

\section{The Planned Economy and the Associations}

It is widely recognized and acknowledged that the North Korean economy broke down during the 1990s in virtually all respects. Thus, the totalitarian design of central control of the economy and all other organizations is no longer valid for North Korea. Today's North Korea is radically different from the design and model described above as intended by the regime. In other words, North Korea is no longer economically totalitarian.

The breakdown of the state economy gave rise to another sector that had until then only existed on a very small scale: the private, unofficial economy. Despite being modeled as a centrally planned economy, North Korea has managed to survive without actually gaining near-sufficient income. These circumstances can be explained in part by the massive flow of foreign aid since 1995 . But the private market system that has spontaneously developed in the country has also played a major role.

The strict regulations on private trade were possible to uphold when the state actually delivered something, and was able to feed its people. But upholding the central planning of the economy and the laws against private ownership and business transactions became impossible when all alternatives to private trade ceased to function. Thus, the centrally 
planned economy became forcibly privatized due to the lack of other alternatives. In 1995, as floods struck North Korea, a number of aid organizations began operations in the country, which had until then denied that any severe, acute food shortages were occurring. The floods became the starting point for an aid program that eventually grew into the World Food Program's largest. Today, it is estimated that about one third or more of the North Korean population is entirely dependent on external aid for their survival (Lintner 2005, p. 51; Chang et al 2008).

Gradually, private markets came to take the PDS's place. At first, these marketplaces operated under a largely illegal framework. But as the authorities themselves were forced to recognize that the people had no alternatives - and that private trade simply could not be completely suppressed - their existence became increasingly open and institutionalized, and even semi-legalized. Today, private sources provide the larger part of all food for North Koreans, according to recent surveys conducted in China (Lee 2008; Haggard and Noland 2009; Chang et al 2008). The judicial recognition of the loss of central command over the economy is a signal of how far the process has progressed. A reform package introduced by the regime in 2002 recognized both the micro-level managerial necessity of individual decision making within the state enterprises, allowing the population a certain extent of private ownership and private trading. Thus, the planned economy has not only been spontaneously transformed by the unlawful changes in the population's economic behavioral patterns; it has even been officially changed by popular pressure.

These institutional changes have had further implications for many other areas beyond the economy. The central planning of the economy has been an important tool for the regime to control the population and reward them politically. Not only occupation but also social position, living standards, organizational belonging and many other aspects of citizens' lives have been controlled by the state. The workplaces have been important as means of control 
for the regime because they accord it the ability to influence the opinions of the population through mandatory indoctrination sessions of various kinds. Even food rations have been distributed through workplaces (Hassig and Oh 2009, p. 66). Yet with the informal sector's predominance over the formal one, these mechanisms have in all likelihood diminished greatly.

As previously noted, the state used the PDS and the planned economy to control and provide incentives for political loyalty. Those considered politically loyal and well-connected were allocated better rations through their more attractive professional assignments (KINU 2008). But because the PDS has virtually ceased operating, officially allocated jobs do not matter as much, although they have not lost all significance. In any case, because the state is no longer the main provider for the main segments of the North Korean population, general loyalty towards the state has probably already decreased (Lee et al 2009).

It should be noted, however, that an official economy still exists in North Korea. The state does own some industries, and its weapons technology and manufacturing sectors particularly its ballistic missile program - hold a relatively high standard, given the overall state of the country's economy. Furthermore, the state has made attempts to revive the PDS and to suppress the unofficial market. This indicates that the regime does in fact regard central planning of the economy as a realistic goal. This dampens the significance of the 2002 economic reforms as truly groundbreaking, and puts them in a more temporarily pragmatic light. However, because food is supplied by the private sector to such a large extent, few scholars believe that the state will be able to reverse the process of private marketization even if it wishes to do so. The PDS is simply too shattered, and the state is probably wary of trying to suppress the market too harshly and risk public unrest and even uprisings against the regime. The state may be reluctant to take such a risk, even to restore the central planning of the economy. 
However, non-economic organizational freedom is still virtually nonexistent, despite the official organization's loss of significance. Mobilization of the population has recently proven possible, for example with the "100 Day Battle" campaign for an increased harvest which reportedly mobilized large segments of the population. Even though the state has been forced to permit an unofficial economy, its institutions still matter. A recently conducted study shows that the vast majority - as many as 80 percent - of refugees surveyed believe that becoming a party or government official is the best way to get ahead in North Korea, while engaging in business is only perceived by 10-20 percent as being the best option (Haggard and Noland 2009).

Still, it remains a fact that the state has lost the ability to centrally plan the economy, even though it guides it harshly. The fact that the economy is strictly controlled but not actually planned probably best brands North Korea in this respect as authoritarian, leaning towards post-totalitarianism because of its reluctance to permit the private economic activity. There exists a plurality of economic organizations - namely, private traders - outside the state's control; in a strictly totalitarian country, there exists no economy beyond state control. This is no longer the case for North Korea.

\section{Summary and Conclusion}

What conclusion, then, should be drawn from these findings? When analyzing a supposed totalitarian "cluster" potentially formed by the six mentioned traits, it is important to bear their organic character in mind. A country with a secret police but without a complete monopoly on all means of mass communication is not totalitarian, neither is a society with a tightly controlled centrally planned economy, but without a guiding, totalitarian ideology. It is the cluster - the dynamics created by the interplay between the six traits - that is crucial, not the separate traits themselves. 
Therefore, the North Korea of today can hardly be considered fully totalitarian. The state apparatus is still exceedingly harsh, and the coercive system of control is still very much in operation. The totalitarian ideology still exists, as does the monolithic power center. But the centrally planned economy does not exist as prescribed by the totalitarian framework. This is especially relevant, because the breakdown of the economy has hit virtually all state institutions. Although all totalitarian criteria are important, the central control of the economy may well be the one that stands out. As bribing and private trade become part of daily life in North Korea, the political incentive structure and system of control has begun to fade. The state simply does not matter as much anymore as it did when North Korea was considered a textbook definition of a totalitarian society. It has thus provided room for influences, behaviors and thoughts other than those which the state endorses to take root.

It is hard to say what this really means, or what it bodes for the future. The totalitarian fostering of loyalty and political correctness is a process that takes place over a long time. It starts at a very early age, and proceeds through mechanisms tightly intertwined with state institutions all through a citizen's life. The changes in North Korea's formerly totalitarian nature may thus not be visible for years or even decades to come. If no drastic changes occur in North Korea's economic behavior, the generation that is currently growing up in the country will be the first one for many decades not to be dependent on the state for provisions, and the first to live under the eroded totalitarian system of control. Only time will tell how this new reality will affect the nature of North Korea.

However, the possibility of a rollback should not be dismissed. Even though the regime has implemented some reforms, they have done so mostly out of necessity. Some measures indicate that the regime still intends to regain totalitarian control. The public distribution system has been restarted on a number of occasions, but has not managed to replace the market. The recent currency denomination is the most recent example of the regime's 
crackdown on the markets, indicating that the regime is nowhere near ready to fully recognize the new market economy.

But the totalitarian institutions have eroded to such an extent that it is hard to believe that the state will ever manage to return them to their previous efficiency of operation. They face a dilemma: the totalitarian institutions require funding, but the North Korean economy was reportedly growing in tiny numbers in relation to its total size as of 2008 , not nearly enough to make a significant difference in the totalitarian institutions (Moon 2009). And as the previous strategy of self-reliance has failed, it would probably be necessary to gain outside capital. This would be difficult to do without risking letting the foreign influences that the totalitarian leadership wants to guard itself against into the country. Either way, the prospects for totalitarianism have been compromised.

There are many more indications to support the argument that North Korean totalitarianism is fading than this paper leaves room for. The economic reforms and birth of SEZ's - Special Economic Zones - in North Korea can in their own right be seen as signs of fading totalitarianism. When leaving room for foreign influences to enter, as is the case with the SEZ's, the state gives up some of its power and makes itself increasingly dependent on outside forces. The increased number of diplomatic relations that North Korea has developed over the last ten years can also be seen as a sign of the Pyongyang regime moving in an increasingly open direction, since they point to the country becoming more and more willing to cooperate and receive impressions from the outside world (Park 2009). The broad, cultural changes that the influx of foreign media and impressions has brought only serves to emphasize the state's weakening power and the erosion of totalitarianism in North Korea (Hassig and Oh 2008). This is one result of the regime's loss of total monopoly on the flow of information that should not be underestimated. The increase of North Korea's external 
economic dependency also drastically compromises the regime's power and ability to fully conduct its own policies.

The North Korean society of today is thus significantly different from the one which preceded the famine of the 1990s. It might not have reached the post-totalitarian stage - it is in some aspects still firmly totalitarian - but it is clear that its control is eroding as a whole.

What some conclude to be the most closed and oppressed society in the world is fundamentally changing. Not least North Korea's neighbors would do right to keep a close eye on the process.

\section{References}

Brzezinski, Zbigniew K. and Carl J. Friedrich (1956), Totalitarian Dictatorship and Autocracy. Cambridge, USA: Harvard University Press.

Cargill, Thomas F. (2009), "A Perspective on Institutional Change in North Korea". North Korean Review, vol. 5, no. 1, pp. 90-104.

Choi, Bong Dae and Kab Koo Woo (2009), "The Development of Farmers' Markets in North Korean Cities". In Park, Philip H, ed., The Dynamics of Change in North Korea: An Institutionalist Perspective. Seoul: IFES Kyungnam University Press.

Chang, Yoonok, Stephan Haggard and Marcus Noland (2008), "Exit Polls: Refugee Assessments of North Korea's Transition”. Working Paper 08-1, Peterson Institute for International Economics.

Eberstadt, Nicholas (2009), The North Korean Economy - Between Crisis and Catastrophe. New Brunswick, USA, and London, UK: Transaction Publishers.

Foreign Policy Magazine (2009), "FAQ \& Methodology". The Failed States Index 2009. Accessed at http://www.foreignpolicy.com/articles/2009/06/22/2009_failed_states_index_faq_methodo logy on Dec. $1^{\text {st }}$.

GlobalSecurity (2009), "Kangsong Taeguk”. Global Security.org, accessed at http://www.globalsecurity.org/military/world/dprk/kangsong-taeguk.htm on Dec. 4th.

Haggard, Stephan and Marcus Noland (2009), "Reform from Below: Behavioral and Institutional Change in North Korea". Working Paper 09-8, Peterson Institute for International Economics; Chang et al. 2008.

Hassig, Ralph and Kongdan Oh (2000), North Korea through the Looking Glass. Washington D.C.: Brookings Institution Press.

Hassig, Ralph and Kongdan Oh (2008), "North Korea's Clash of Cultures”. North Korean Review, vol. 4, no. 2, pp. 68-82.

Hassig, Ralph and Kongdan Oh (2009), The Hidden People of North Korea-Everyday Life in the Hermit Kingdom. Lanham, Maryland: Rowman \& Littlefield Publishers, p. 161.

Kim, Ilpyong J. (2003), Historical Dictionary of North Korea. Laham, Maryland and Oxford: The Scarecrow Press Inc

Korean Institute for National Unification (KINU) (2008), White Paper on Human Rights in 
North Korea 2008. Seoul, Korea: KINU

Lankov, Andrei (2006a), "The Natural Death of North Korean Stalinism”. Asia Policy, no. 1, Jan. 2006, pp. 95-121.

Lankov, Andrei (2006b), "North Koreans Turned on but Tuned Out". Asia Times 2006-06-28.

Lankov, Andrei (2007), North of the DMZ - Essays on Daily Life in North Korea. Jefferson, North Carolina: MacFarland Publishers.

Lankov, Andrei (2008), "North Korea Adopts New Propaganda Tool”. Korea Times 2008-1123. Accessed on Dec. $15^{\text {th }}$ at http://www.koreatimes.co.kr/www/news/opinon/2008/11/137 34882.html.

Lee, Aie-Rie, Hyun-chool Lee, Ji-Yong Lee and Il-Gi Kim (2009), "The Paradox of North Korea's Ideological Radicalism: Shaky Social Basis of Strengthening Ideological Campaigns". North Korean Review, vol. 5, no. 1, pp. 46-61.

Lee, Joo Il (2009), “The Democratic People's Republic of Bribery”. Daily NK, unknown publishing date. Retrieved on Dec. 10th at http://www.dailynk.com/english/keys/2004/17/03.php.

Lee, Young -Hoon (2008), "Changes in the North Korean Economy Reported by North Korean Refugees". North Korean Review, vol. 4, no. 2, pp. 49-58.

Lintner, Bertil (2005), Great Leader, Dear Leader: Demystifying the Kim Clan. Chiang Mai, Thailand: Silkworm Books.

Linz, Juan (2000), Totalitarian and Authoritarian Regimes. London: Lynne Rienner Publishers.

Moon, Ihlwan (2009), "North Korea's GDP Growth Better Than South Korea's". Bussinesweek 2009-06-30.

Oberdorfer, Don (2001), The Two Koreas. New York: Basic Books.

Park, Kyung-Ae, (2009), "Regime Change in North Korea?: Economic Reform and Political Opportunity Structures". North Korean Review, vol. 5, no. 1, pp. 23-45.

Scobell, Andrew (2008), "The Evolution of North Korea's Political System and Pyongyang's Potential for Conflict Management". North Korean Review, vol. 4, no. 1, pp. 91-108.

Scobell, Andrew (2006), "Kim Jong Il and North Korea: the Leader and the System". Strategic Studies Institute Monograph, March 2006.

Yoo, Gwan Hee (2009), “Why Don't North Koreans Fight Back?”. DailyNK 2009-12-29. Accessed on Dec. $10^{\text {th }}$ at http://www.dailynk.com/english/read.php?cataId=nk02900\&num=5755. 